\title{
Early Implementation of School Reform: How Observation of Literacy Practices Reveals the Impact of Accountability Systems on the Reform Process
}

\author{
by Devon Brenner, D. Kay Brocato, and Terri Kurz
}

This program (Accelerated Schools Plus) was voted in like 100 percent, everybody voted for it because we liked what it said, that it didn't have a scripted plan to follow, it had flexibility. We like that about it. We all want all children to achieve to their potential ... . Accelerated Schools will probably be more successful here if, and it's something that we can't control, it's the No Child Left Behind and all the testing and the benchmarks and the state tests, we have to do it this way. l'd like to be a lot more free but I can't help that, and I feel like that's something that holds us back.

--Ms. Ward, a $4^{\text {th }}$ grade teacher reflecting on the implementation of school wide reform model

In the wake of the No Child Left Behind Act, with its emphasis on research-based solutions for school improvement, more and more schools are turning to comprehensive reform models to help their schools meet performance goals (Borman, Hewes, Overman \& Brown, 2003). However, as Ms. Ward observed, implementing school reform is no straight forward task, and may be compromised by teachers' focus on "the test."

Emphasis on preparing students for the test may obscure teachers' ability to examine their own teaching practices, to reflect on the strengths and weaknesses of the school's instructional program, or to respond to the needs of diverse learners. Accelerated Schools Plus is just one of many comprehensive school reform models, one that is being widely adopted by schools eager to meet the requirements of state and federal accountability. This reform model, developed by Henry Levin and his colleagues at the Accelerated Schools Project, is described as an approach designed to bring disadvantaged students up to grade level by the end of sixth grade (Levin, 1987). The effectiveness of this model has been examined with at-risk students in urban schools (e.g. Knight \& Stallings, 1995; Miron, St. John, \& Davidson, 1998), but has not been examined with at-risk students in rural schools. Here we provide a case study of a rural, southern school over the first year of implementation of Accelerated Schools Plus with a particular focus on the ways in which observation of literacy practices, using the CIERA School Change Observation Scheme (Taylor \& Pearson, 2000), is consistent with and/or differs from the selfevaluation of instruction afforded by the implementation of the reform model.

We decided to focus on literacy instruction because literacy development, particularly reading and writing for meaning, is an important aspect of the Accelerated Schools Plus model. In addition, the area of literacy is generally where the biggest achievement gap between successful and unsuccessful students occurs. As Bloom (2003) cautions, wholeschool reforms usually take 3 to 5 years to implement, therefore, a fair measurement of any impact requires data to be consistently collected and analyzed for at least that length of time. As such, this paper does not purport to make judgments of the effectiveness of the Accelerated Schools plus model on student achievement. Instead, our research questions focus on: (a) What literacy teaching practices were observed as the school began implementing Accelerated Schools Plus? (b) How do literacy practices observed compare to research on effective literacy practices? (c) How do literacy practices observed compare with teachers' evaluation of their classroom practice as a result of implementation of the Accelerated Schools Plus Model? 


\section{The Reform Model}

The philosophy behind the Accelerated Schools Plus (ASP) model consists of three basic tenets: 1) unity of purpose - the whole school community has a unified focus; 2) empowerment with responsibility - the entire school community makes important educational decisions and takes responsibility for them, and; 3) building on strengths - the strengths of everyone in the school community are identified and built upon (Hopfenberg \& Levin, 1993).

The process begins with the school community identifying priorities that will help the school move toward change. These priorities become the focus of cadres, which are teams of teachers, parents, administrators, and staff. These cadres work to assess strengths and weaknesses and then to implement strategies aimed at improving the curriculum, instruction, and organizational practices of the school in order to address the identified priorities and to ameliorate identified weaknesses. According to the ASP literature (National Center for Accelerated Schools Plus, 2005), the curriculum after implementation should focus on higher-order skills and activities, be applicable to everyday problems and events, and have language development (reading and writing for meaning) as the primary emphasis in all subjects. Instruction should encourage active student involvement by having the students work in pairs or small groups on studentcentered, hands-on activities. The organizational practice of the school should encourage active teacher participation in decision making and an increase in parent and community involvement (Knight \& Stallings, 1995).

ASP aims to improve achievement for all students, including typically low-performing students, by effecting changes at the school and classroom level. As Kober (2001) notes, "the fundamental goal of standards-based reform is to ensure that all students become academically proficient. We must close the racial/ethnic achievement gap while simultaneously improving achievement across the board" (p. 9). The ASP model aims to close this gap by bringing about change in the teaching and learning that take place in classrooms as the school community works to identify strengths and address weaknesses identified at the beginning of reform.

\section{School Setting}

Hill Elementary School is located in a small city in the rural south. Hill Elementary consists of twenty-seven fourth and fifth grade classrooms. The faculty at Hill includes one principal, one assistant principal, twenty-five regular education teachers, two special education teachers, one full time counselor, one part time counselor, a reading specialist, a media center librarian, and approximately seven full time enrichment (gifted, music, art, etc.) teachers.

Hill Elementary School had 563 students in attendance during the year of the study. Approximately $65 \%$ of students were African-American, $31 \%$ were White, $3 \%$ were Asian and $.5 \%$ were Hispanic. The percentage of students in the lowest quartile on statewide assessments in 5 th grade language was $9 \%$ and reading was $11 \%$. Sixty-seven percent of the students in the school were eligible for free and/or reduced lunch. The school is accredited by Southern Association of Colleges and Schools and had earned a Level 3 rating (on a 1-5 scale, with 1 the lowest) on the state accreditation system.

Hill used Title I funds to purchase and implement Accelerated Schools Plus. This particular model was selected for several reasons. The adoption team was impressed with the caliber of student work and calm environment they saw when they observed an Accelerated School, and shared the model with the rest of the faculty. The faculty liked 
the amount of teacher control over decision making, and they appreciated that ASP is flexible and does not require a specific curriculum or teaching script.

\section{Method}

In order to understand instructional practices at the beginning of reform and to analyze whether the ASP processes help teachers to identify instructional strengths and weaknesses, we used both quantitative and qualitative data. Quantitative data include classroom observations using the CIERA School Change Observation Scheme collected in the fall of the implementation school year. Qualitative data include interviews with classroom teachers in the fall, and year-long and end-of-year data on ASP implementation such as participant-observation of ASP meetings and internal documents created during the implementation of the reform model.

All three researchers are white, middle-class assistant professors with a range of involvement at Hill. Brenner has a son who has been attending Hill for two years, and was the parent representative on the reform model selection team. She was as a member of the writing cadre this school year and has regular interactions with teachers and students. Brocato has a daughter who has been attending Hill for one year, and regularly attends family involvement events. She serves as a member of the school and community cadre. Kurz does not currently have a role in the school but is interested in school-wide reform and classroom observation.

\section{Participants}

In order to examine teachers' classroom behaviors during literacy instruction we observed reading instruction in five fourth and five fifth grade regular education classrooms. School administrators selected ten teachers ranging in teaching and literacy instruction expertise. Nine females and one male were chosen. Eight of the teacher participants in the study were Caucasian and two were African American, a proportion consistent with the overall school population. Two teachers were in their first year of teaching, four teachers had between two and five years of teaching experience, and four teachers had over ten years of teaching experience.

\section{Materials}

In order to observe classroom practices of teachers during literacy instruction we used the CIERA School Change Classroom Observation Scheme (Taylor \& Pearson, 2000). This instrument is a low-inference measure which uses time sampling in order to record events in the classroom. During 5 minute intervals the observer records the most salient literacy activities as well as who was providing instruction, the grouping pattern in use for that event, the major literacy category, the materials being used, the teacher interaction styles being used, and the expected responses of the students for the literacy activity (see Figure One). In addition, the number of students who appear to be engaged and on task is recorded at the end of each 5 minute interval.

\begin{tabular}{|l|l|}
\hline Level 1 Provider & Who provides instruction (i.e. classroom teacher, aide, specialist, etc.) \\
\hline Level 2 Grouping & Instructional grouping (i.e. whole class, small group, individual, etc.) \\
\hline Level 3 Focus & Major academic area (reading, writing, etc.) \\
\hline Level 4 Activities & $\begin{array}{l}\text { Specific literacy activity (i.e. vocabulary, comprehension strategy, Word } \\
\text { ID, etc.) }\end{array}$ \\
\hline
\end{tabular}




\begin{tabular}{|l|l|}
\hline Level 5 Materials & i.e. textbook, narrative trade book, worksheet \\
\hline $\begin{array}{l}\text { Level } 6 \text { Interaction } \\
\text { Style }\end{array}$ & Nature of interaction (i.e. modeling, discussion, telling, etc.) \\
\hline $\begin{array}{l}\text { Level } 7 \text { Expected } \\
\text { Pupil Response }\end{array}$ & How children are to respond (i.e. reading, oral turn taking, writing, etc.) \\
\hline
\end{tabular}

Table 1: Levels of Observation for the CIERA School Change Observation Scheme (Taylor and Pearson, 2000)

Each of the participating teachers was observed for two periods of reading instruction, generally an hour or more of instruction. Two separate observations by different observers were recorded for each teacher. We observed a total of 129 five-minute observation periods, allowing us to document the relative frequency of various aspects of classroom instruction. The inter-rater reliability for this instrument was high $(>.80)$ among the three observers. The ethnic make-up of the students in classrooms observed was similar to that of the whole school, including 67\% African-American, 30\% White, $2.6 \%$ Asian, and .4\% Hispanic.

Interviews were conducted with nine of the ten teachers. We asked questions pertaining to the school climate, classroom practice with a focus on literacy instruction, strategies for responding to a culturally diverse student population, and the initial implementation of ASP.

\section{Effective Literacy Instruction}

We wanted to understand the ways in which the ASP processes for the first year of implementation help teachers to identify literacy teaching strengths and weaknesses and set appropriate goals for year two of implementation of reform. Taylor, Pearson, and their colleagues at the Center for the Improvement of Early Reading Instruction (CIERA) (Taylor, Pearson, Clark, and Walpole, 1999; Taylor and Pearson, 2000; Taylor, Peterson, Rodriguez, and Pearson, 2002) have correlated items on the CIERA School Change Observation Scheme with student achievement scores over all, and with students' growth on a variety of measures of reading achievement, (i.e. words read per minute, word identification, etc.) and have determined that more effective schools and more effective teachers in the fourth through sixth grade share a variety of characteristics. Teachers in these classrooms 1) spent nearly twice as much time in small group instruction than in whole class instruction, 2) spent significantly more time coaching students, particularly coaching in word recognition during reading (in least effective schools, teachers were more likely to spend time telling and/or engaging in recitation), 3) asked more higher level questions which required students to engage in active responding (reading, writing, and manipulating) 4) were less likely to engage students in passive responding (e.g., reading turn-taking, oral turn-taking as during a recitation, listening to the teacher), 5) had a higher percentage of students on task (an average of $96 \%$ in highly accomplished teachers' classrooms $61 \%$ for least accomplished), and 6) engaged more frequently in word-level activities (e.g. phonics, word recognition strategies, spelling).

The CIERA results are consistent with a great deal of research on effective literacy instruction, which documents the importance of engagement, small group instruction, comprehension instruction, higher-order questions, time spent reading and writing, and a 
balance between meaning or holistic instruction and skills instruction (e.g. Allington, 2003; Knapp, 1995; NICHD, 2000; Pressley et. al., 2001).

\section{Literacy Instruction at Hill}

We observed 129 5-minute periods of literacy instruction in 10 classrooms, and have tallied the occurrences of various instructional practices in order to describe the teaching practices we observed. The tallies are supplemented by teachers' descriptions of their own practice from interviews. As is typical in many middle-grade classrooms, all of the instruction we observed $(100 \%)$ was provided by the classroom teacher. No other adults were present in any classroom, with class sizes ranging from 20-25 students (though Ms. Carson did wish for "an aide-more grown-ups" so she could spend more time with individual students).

We had asked teachers to invite us to observe "reading instruction," and that is mostly what we saw. Seventy-one percent of the time, the focus of instruction observed was reading. Other times, the focus may have been on writing, or a combination of content areas, as when students rotated through a variety of centers including math and science centers.

\section{Grouping}

Overall, we observed less small group instruction than was found in even moderately and least effective schools and classrooms in the CIERA studies. The CIERA team noted that teacher-guided small group instruction was highly correlated with student achievement. Small group instruction, particularly teacher-led small group instruction, often provides teachers a time to focus on target skill and strategy instruction with particular groups of students (Fountas and Pinell, 2001. Small group instruction can also increase the amount of time students engage in reading, writing, and thinking.

\begin{tabular}{|l|l|}
\hline Whole class & $74 \%$ \\
\hline Small group & $18 \%$ \\
\hline Teacher led small group & $0 \%$ \\
\hline Individual or pairs & $7 \%$ \\
\hline
\end{tabular}

Table 2: Grouping Practices

Nearly three-fourths of the instruction we observed at Hill was whole-class instruction, often recitation or some other passive form of teaching (described in more detail below). When teachers did require students to work in groups, the teacher's role was to supervise the behavior of the whole class, rather than to work with small groups of students on targeted literacy instruction. During group work, children worked on a variety of projects such as stringing mobiles, writing animal poems, typing paragraphs into word processors, and measuring shells. We saw no examples of teacher-led small group instruction. During $7 \%$ of observation periods, students engaged in either working in pairs (generally reading in pairs) or in individual seat work.

It is possible that we did not observe as much small group work as actually takes place during literacy instruction. Teachers described themselves spending more time using small groups, pairs, and individual instruction than we observed. Ms. Ashe, for example, 
described using group work frequently, saying, "At least three or four times a week we're doing some type of group activity with our instruction."

This discrepancy may be due to the nature of observations. Knowing we wanted to "observe instruction," teachers may have planned whole class instruction so that we would be able to observe them "teaching" rather than monitoring small group instruction.

However, only one teacher, Ms. Golden, described using teacher-led small groups. She uses three "guided reading groups" with students of differing achievement levels but told us that she was only able to get to each group "about once every two weeks."

In interviews, the teachers expressed a tension between their desire to teach using small group instruction and their concerns over student behavior. As Ms. Sanders noted, "This is quite a talkative group so we don't get to work in groups as much as we like, but we do work in groups." Ms. Ashe also didn't do as much small group instruction as she would like because of classroom management issues, saying, ". ... you know, l'm finding it true that with the group that I have I cannot have any down time, they have to be busy or I lose total control, so that's hard for me."

\section{Instructional Materials}

All of the teachers reported that they teach with both the basal and trade book literature. Teachers described spending most of the semester teaching the stories out of the basal, and culminating with a whole class novel. Two teachers teach almost exclusively with trade books, and use the basal as a guideline for instruction. Worry about the accountability system convinced many teachers that they should use the basal. As Ms. Ward told us,

Honestly, l'd do more trade books, if it weren't for that, when I taught $5^{\text {th }}$ I did all trade books, no basal, the children like that more. But because of the state test you have to make sure you get these certain skills in and you have to document everything, and you know you pretty much have to use the basal and trade book in any free time that you have, which I hate.

Ms. Oliver described using the basal to plan, saying, "Right now, I look at my basal unit, a week before we do the story and I look at competencies and I plan activities to go with whatever skills to reinforce .... . We'll do a puppet show and work on skills you have to do with um, how to use different inflections. I look at it and see what I have, what 's in my mind to go with it, I use the basal as a springboard." Use of the basal may be one reason for fairly frequent use of worksheets and workbooks, which were found in $40 \%$ of observations.

\begin{tabular}{|l|l|}
\hline Narrative textbook & $17 \%$ \\
\hline Informational textbook & 0 \\
\hline Narrative trade book & $30 \%$ \\
\hline Informational trade book & $14 \%$ \\
\hline Student writing & $20 \%$ \\
\hline Board/Chart & $14 \%$ \\
\hline Worksheet & $40 \%$ \\
\hline Oral presentation & $2 \%$ \\
\hline Pictures & $13 \%$ \\
\hline Computer & $12 \%$ \\
\hline Other & $7 \%$ \\
\hline
\end{tabular}

Table 3: Materials for Instruction 
Whether basing instruction on the basal or trade books, teachers were most likely to teach with narrative texts. Informational trade books were observed in use in $14 \%$ of observation periods, always during centers instruction in two of the ten classrooms as small groups of children consulted books on animals or weather to write paragraphs. We saw no examples of children reading informational texts from the basal (although several selections in the basal are informational in nature), no examples of either a teacher or whole class reading from informational texts, and no examples of instruction on how to read and comprehend informational texts. Our findings were consistent with those of the CIERA team and of Duke (2000) —most teachers are far more likely to provide opportunities to read narrative texts than information, in spite of the facts that adults primarily read informational texts and that NAEP assessments and other accountability systems are putting increasing emphasis on informational texts.

\section{Activities}

Many teachers described a typical week of instruction. Generally, children and/or the teacher would read a text aloud (basal or trade book) in a whole class setting, stopping frequently to discuss the story. Then, children would write answers to questions about the text and complete worksheets or activities. At the end of the week or novel, children generally constructed projects and/or completed assessments from the basal focusing on mainly lower level (literal) comprehension. Teachers' descriptions of reading instruction were consistent with observations of activities.

\begin{tabular}{|l|l|}
\hline $\begin{array}{l}\text { Talking-lower level } \\
\text { meaning of text }\end{array}$ & $37 \%$ \\
\hline $\begin{array}{l}\text { Writing-lower level } \\
\text { meaning of text }\end{array}$ & $23 \%$ \\
\hline $\begin{array}{l}\text { Talking-higher level } \\
\text { meaning of texts }\end{array}$ & $16 \%$ \\
\hline $\begin{array}{l}\text { Writing-lower level } \\
\text { meaning of texts }\end{array}$ & $14 \%$ \\
\hline $\begin{array}{l}\text { Listening to texts read } \\
\text { aloud }\end{array}$ & $30 \%$ \\
\hline Reading connected texts & $16 \%$ \\
\hline Independent reading & $0 \%$ \\
\hline Paired reading & $0 \%$ \\
\hline Writing & $17 \%$ \\
\hline Vocabulary & $0 \%$ \\
\hline Comprehension Skill & $13 \%$ \\
\hline
\end{tabular}




\begin{tabular}{|l|l|}
\hline Comprehension Strategy & $5 \%$ \\
\hline Word identification & $2 \%$ \\
\hline Other & $24 \%$ \\
\hline
\end{tabular}

Table 4: Activities

Students were frequently engaged in talk or writing about lower-level meaning of the text being read. Teachers were nearly twice as likely to ask more literal, lower level comprehension questions as to ask open-ended or higher order thinking questions about texts read. Students talked about the lower level meaning of texts in $37 \%$ of segments, and wrote about lower level meanings of text in $23 \%$ of segments (more than half of all observation periods), but in talking or writing about higher level meaning in less than a third. A few children wrote poems or other responses to readings. In contrast, the CIERA team found that time spent on higher level meaning (both oral and in writing) was positively related to student growth.

Time spent reading is correlated with achievement, however, we rarely observed students reading texts. Instead, students spent a considerable amount of time listening to texts read aloud, either by the teacher or by their classmates (recorded in $30 \%$ of observations, nearly twice as many segments as reading connected text). Ms. Golden described a typical week, which included little reading during the school day, "We do a story, I introduce the vocabulary words, and the first reading either I do it or I let them listen to it on tape, to model fluency, and it's homework every night to read the story for repeated reading."

When students did have time to read, reading took place during centers instruction in a few classrooms, in which one or two groups of students read texts as part of a center activity, and during which time very little reading actually occurred. In a few cases, reading connected texts included students reading drafts of their writing to each other, taking turns reading aloud, and choral reading. During our observations periods, we did not see examples of independent or paired reading, although teachers did set aside time for independent reading during the school days. During subsequent visits to the school for other reasons,, independent reading of Accelerated Reader (Renaissance Learning, 2004 ) texts was observed in each of the classrooms. Ms. Carson described having students read for 30 minutes a day, saying "Kids do better when I give them 30 minutes, they carry books around, they enjoy it. It's forced those who don't want to, to read."

During read-alouds and other frequent activities, teachers were fairly unlikely to engage in explicit teaching of skills and strategies. Comprehension skills and strategies are two distinct categories in the Observation Scheme. Comprehension skills include lower level comprehension activities such as identifying main idea or cause and effect. Students engaged in activities to foster comprehension skills in $13 \%$ of segments observed, the majority of observations originating in a single teacher's classroom. Comprehension strategy instruction includes explicit instruction on transferring a routine for comprehending to other reading situations, such as when one teacher suggested that "good readers predict before they read" and is correlated with increased achievement. Comprehension strategy instruction was observed in $5 \%$ of segments observed, and nearly $2 / 3$ of those segments came from one teacher's classroom. 
Students were even more unlikely to be given word-level skills instruction such as word recognition skills, phonics instruction, and spelling instruction. Word-level skills instruction was observed in $2 \%$ of segments. Although word level instruction (vocabulary, morphology, word identification) is correlated with achievement, we did not observe these types of instruction in any extended way. We did observe teachers stopping to discuss the meanings of individual words or to help students decode new words during read alouds or as a prereading activity, but never with a focus on developing strategies for understanding the meanings or pronunciation of new words. CIERA found that both comprehension strategy and word-level activities were correlated with higher achievement in middle grades classrooms.

In interviews, teachers did not describe very much skill, strategy, or word level instruction. When teachers were asked to describe their best and typical reading teaching practices, teachers rarely spoke of skills and strategies, except as lessons that come with the basal. Ms. Ashe described a typical lesson, "I would introduce whatever skill, just like today we were paraphrasing, introduce the skill, give them an example, today we did not do group work, I let them read and paraphrase after I had introduced them to it, then let them follow up with maybe a workbook page that goes along with that skill in our literacy program." Only Ms. Carson told us that she attempts to teach comprehension, but that "it's hard getting kids to understand what they've read." No teachers mentioned teaching phonics, decoding strategies, or word identification strategies when they described their teaching strengths, although Ms. Oliver expressed concern about students' vocabulary knowledge, saying, "students don't have the background knowledge. This morning a child didn't know any definition of 'brand' whatsoever. That's not a word l'd say is above $4^{\text {th }}$ grade, so vocabulary is difficult."

Some teachers mentioned teaching the skills listed in the state's framework, such as paraphrasing or reading with expression. Three teachers mentioned teaching spelling, a subject area we did not observe. The teaching of spelling seemed to center around memorization of spelling lists, and not teaching in such a way as to help children transfer their knowledge of words, letters, and sounds to the act of reading.

Most of the teachers did open the school day with skills activities such as Daily Oral Language (Byers, 2001), in which students correct punctuation, grammar and other errors in a sentence written on the board, or other activities designed to reinforce skills. Skill instruction of this sort is generally unrelated to the reading and writing tasks that take place during reading instruction. As Ms. Golden told us, "I try to start the day with minilessons, if I don't start with reading minilessons I start with something that helps with test prep."

Students engaged in the activity of writing in $17 \%$ of observation segments. Students spent relatively little time writing during reading instruction. We assume that children write more than the observations indicate, primarily because we were invited to observe reading instruction. Six of the nine teachers interviewed described teaching writing on a regular basis, though only two described themselves as "integrating" writing and reading. One teacher worked on a team in which reading and language (which includes writing) were taught by two different teachers. Others save writing for particular time periods, such as Ms. Sander's "Writing Fridays" in which students draft, revise, and complete an entire piece, generally a paragraph, and Ms. Carson's daily journal time. Students are more likely to be asked to write short pieces in response to prompts (similar to the state's standardized tests) than to engage in creative writing or other kinds of writing. Ms. Ashe described challenges getting students to write, "They're not eager to write, by all means, and I would say a paper we would do maybe once every 10 weeks, a different type of 
expository or descriptions, something like that. They're not receptive to writing. I don't know why."

\section{Teacher Interaction and Expected Pupil Response}

Students tend to learn more when they are actively engaged, particularly when they are engaged in reading and writing (Elley \& Mangubhai, 1983; Guthrie et al., 2001; Taylor, Frye, \& Maruyama, 1990). However, at Hill, Teachers were more likely to ask students to engage in passive than active activities. Often times, even when students were given opportunities to be actively engaged (reading, writing, manipulating, talking to others) these activities were likely to be short and interspersed with more passive responding. For example, students were observed listening to the teacher read aloud, and stopping to write answers on a worksheet. Sustained active engagement was infrequently observed, particularly sustained writing, other than in centers in a few teachers' classrooms.

\begin{tabular}{|l|l|}
\hline Telling/Giving information & $48 \%$ \\
\hline Modeling & $1 \%$ \\
\hline Recitation & $50 \%$ \\
\hline Discussion & $5 \%$ \\
\hline Coaching/Scaffolding & $22 \%$ \\
\hline Listening/watching & $33 \%$ \\
\hline Reading aloud & $23 \%$ \\
\hline Check work & $12 \%$ \\
\hline Other & $10 \%$ \\
\hline
\end{tabular}

Table 5: Teacher Interaction

\begin{tabular}{|l|l|}
\hline Reading & $11 \%$ \\
\hline Reading turn-taking & $9 \%$ \\
\hline Orally responding & $12 \%$ \\
\hline Oral turn taking & $47 \%$ \\
\hline Listening & $47 \%$ \\
\hline Writing & $38 \%$ \\
\hline
\end{tabular}




\begin{tabular}{|l|l|}
\hline Manipulating & $12 \%$ \\
\hline Other & $12 \%$ \\
\hline
\end{tabular}

Table 6: Expected Pupil Response

In least effective schools, teachers are also more likely to spend time telling and/or engaging in recitation, instructional styles which lead children to more passive engagement. Mrs. Ward described her instruction as including frequent recitation, saying, "We read a story, I have them take turns reading different paragraphs. We'll discuss-we discuss and discuss and discuss - and the kids are like, 'Can we read now?' I want to make sure they're comprehending and I want to get their point of view and I want to know what they are understanding and misunderstanding so we can get it straight."

Teachers also coached students in over $20 \%$ of segments, a teaching strategy correlated with achievement. The CIERA team found that coaching students, especially during reading for word recognition strategies, is correlated with achievement. At Hill, teachers engaged in frequent coaching, helping students find the right answer to comprehension questions or to figure out words while reading aloud.

During the observations, almost all students were almost always on-task. Students at Hill, whether responding passively or actively, appeared to be highly engaged. Student engagement has long been linked to student achievement, in that time on task matters (see, e.g., Stallings \& Kaskowitz, 1974). Students generally seemed to be both following along, responding appropriately, and actively interested in their coursework. In contrast to our findings, however, several teachers expressed concerns about student behavior. Ms. Oliver told us:

We're at a crisis with discipline, and it's been discussed repeatedly this year and last year . . . it's a real problem with students not respecting teachers and teachers not respecting students and sometimes, things just getting out of hand too quickly, with students being more concerned with social things. . . As a result it really eats into our instructional time.

\section{Conclusion}

The teaching practices at Hill are consistent with teaching practices which are moderately but not highly effective. Strengths of the instructional practices include the consistently high level of student engagement. Teachers used a wide variety of instructional practices characteristic of effective literacy teachers, including basals, literature based approaches and independent reading, and generally had a strong instructional focus. Relatively frequent use of coaching and high student engagement are strengths of teaching practice.

When the teaching practices observed and described at Hill are compared with both research on effective literacy instruction, several potential areas of growth emerge. For example, improved literacy instruction at Hill might include increasing time spent on higher level comprehension, word-level activities, and strategy instruction. Other potential growth areas include increasing the amount of time students spend actively reading and writing, including more writing in response to texts read, reorganizing instruction to include more time teaching using small groups (particularly teacher-led small groups), pairs, and individual grouping practices, and decreasing the amount of time students spend in passive instruction such as listening and recitation. 


\section{Literacy Instruction at Hill: From the Perspective of the Reform Model}

The procedures required by the reform model might be expected to help the faculty identify these same strengths and potential areas of growth. As the first year of implementation came to a close, this had not yet happened. Through ASP, the formal structure for examining and increasing reading achievement is the reading cadre. The reading cadre was a group of teachers, parents, and other school personnel charged with analyzing instruction and achievement in reading, setting goals for improvement, and developing recommendations for action. Through a formal process ASP calls "taking stock," the reading cadre collected and analyzed data. Taking stock is intended to be a four month process, where teachers follow guidelines and complete a variety of paperwork which is intended to guide the cadre through the process of identifying both strengths and challenges. After taking stock, cadres are instructed to engage in an inquiry process, during which they develop and test theories about the causes of challenges. After inquiring into the hypotheses, teachers are to identify possible solutions, eventually leading to priorities and an action plan for the next year. This year-long, deliberate process is intended to help teachers move beyond snap judgments about strengths and weaknesses and to carefully examine a variety of data to come to informed decisions about how to improve teaching and learning.

During the taking stock process, the cadre members examined a wide variety of data to examine reading instruction at Hill. The reading cadre discussed concerns about diverse learners such as English language learners; ethnically, racially, and economically diverse students; and transfer students who move in and out of the district. They conducted attitude surveys of students about their views of reading. They collected teacher surveys which primarily focused on the implementation of the Accelerated Reader program. They talked with teachers and went room to room to identify teaching materials available for instruction such as textbooks and supplements. They examined student work samples, and they looked at whole school and individual classroom results for previous years' on the state's standardized test, known as the MCT.

In spite of the wide variety of data collected and analyzed during the taking stock process, the members of the reading cadre ultimately only attended to data pertaining to the standardized test. The reading cadre had to prepare a report at the end of the first year, summarizing the work of the taking stock and inquiry processes, identifying strengths and challenges, and describing the reform focus they would establish for year two of implementation of ASP. The cadre reported that in reading the fourth grade was strong in "vocabulary" and "work place data" and should work on "expanded comprehension" and "main ideas and details." The cadre also determined that the fifth grade was strong in the areas of "vocabulary" and "word structure," and should work on "workplace data" and "expanded comprehension." These phrases, used to describe instructional strengths and challenges in reading, are word-for-word the same as sub-categories of the state's reading test. (Work place data refers to reading charts and graphs.) The strengths are the areas in which the highest percentages of students scored proficient or above, and the challenges are the areas in the greatest proportion of students scored below basic. In spite of the broad range of data they examined, the reading cadre ultimately paid little attention to anything other than the standardized test. Ms. Golden described the work of the reading cadre during the first year, saying, "We identified the strengths and weaknesses for our grade and we're trying to find ways to improve our weaknesses and keep our strengths, add to our strengths. We did it by grade level, I think . . . So we went through the overall MCT scores, you know how they break them down, that's what we looked at." 
This focus on the standardized test was directly translated into the reading cadre's action plan for year two of implementation of ASP. Based on concerns about the subcategories on the standardized test, the reading cadre would work to help the school to obtain and distribute test prep items, including, as they wrote, "MCT Coach books; bubble sheets; the MS Department of Education examples of practice tests for MCT Reading' transparencies; a current curriculum map; a skills checklist; open-book testing; pre- and post-tests; and an inventory of each classroom's basal materials." The cadre saw its focus on test scores as one of the things they did well, reporting in their end-of-year summary that strengths included "Unity of purpose in improving MCT Reading scores."

This emphasis on the standardized test also affected teacher's participation in professional development. In reference to the workshops she had attended provided by the ASP facilitator on ASP topics such as "powerful learning," Ms. Ward said, "I don't want these lessons that look good on a video but then my kids still can't pass the MCT."

During the first months of taking stock, the cadre discussed many different aspects of diversity affecting students' reading achievement. Teachers on the cadre expressed concerns about teaching an increasing population of English language learners. They worried about whether or not the curriculum meets the needs of the school's ethnically, racially, and economically diverse student body. They fretted over the large numbers of transfer students who move in and out of the district. And they recognized vast disparities in students' achievement levels upon entering fourth grade.

Concerns about diversity expressed in cadre meetings were echoed by teachers who participated in interviews. Many teachers expressed concerns about diversity in achievement, including Ms. Voles.

We're struggling with the fact that we have such a wide range of levels in our classrooms. They are heterogeneously grouped. And so we have children working as low as a first grade level in the $5^{\text {th }}$ grade up to a high school level. And so you're trying to meet the needs of all those children and make everyone work to their greatest capacity and at the same time not going too high above the lower level children and not holding the higher level children back.

Ms. Oliver described students similarly. "We have students who complain we don't give enough homework, and we're being challenged to keep them challenged. And then all the way to the ones on a kindergarten or first grade level, they're barely able to read and write, and we're trying to get them up to $4^{\text {th }}$ grade level." Ms. Ward described the challenges posed by such a range in achievement, and how she hoped that ASP would help her to teach all students.

I feel like no matter what I do sometimes, I still don't reach all of them. I don't know that you can ever each them all but it's every teacher's goal. I feel like when I reach the ones, when I get them to understand, then I'm boring the others. I want them all to be interested and motivated and engaged, that's what we all want. I don't know if a program can accomplish that but I hope so.

Teachers also described cultural diversity in their classrooms. Hill Elementary has a majority white and female staff, a majority black student population, and small but notable numbers of children from families who have recently immigrated to the United States. Ms. Ward reacted to this diversity:

I try to include everyone, that's a challenge. . . I have one from China and one from Nepal, and some that moved here from Arizona or that have been in the 
district all their lives. And I have some that live in nice houses, some that don't. They just have lots of different experiences to bring.

Many teachers who teach students of races and cultures not their own attribute differences in children to the home environment, expressing concerns about parents' ability to raise their children (Purcell-Gates, 2002). Ms. Ashe echoed this sort of attitude, saying, "I have a lot of differences that I have to deal with, and that being maybe differences at home, home life, not knowing what that's like and then having to try to better them here in school, while I have them." Other teachers echoed these concerns about student home life, including Ms. Sanders, who told us, "There needs to be a lot of character education taught. There's a lot that they're not getting before they come to us, it's really hard to deal with, to deal with the issues that they come to school with."

Literacy teachers might adapt instruction to take advantage of student diversity by decreasing the amount of whole class and passive instruction, increasing small-group instruction and time students spend actively engaging in reading and writing. More explicit instruction in skill and strategy use, particularly word-level and comprehension instruction through coaching, can support diverse learners. These were all challenge areas identified by observations. However, although the reading cadre did raise diversity issues in relation to reading instruction and achievement early in the work of taking stock, the ultimate focus on standardized test scores overshadowed concerns about addressing diversity.

The school and community cadre was the only cadre that did not have a specific content area (and therefore a standardized test) to address. Ms. Carson was a member of the school and community cadre. She described that cadre's focus on students and their "backgrounds."

We took focus off the kid, we decided we can't control their home, their background, when they come to school. . . . When we really asked, "Why are they acting this way?" then we came up with what are, what will we have under our control? We can change the environment and how we treat them, not that we're doing it negatively, but the whole outlook on the kids themselves, we realized we need more training on the kids, what do you do when you are faced with different cultures, kids from different backgrounds. When you look at a child and say, "Look at me when I'm talking to you." But when you talk to an African American they'll look at the floor, that's not disrespect, that's them showing that you are above them.

\section{Discussion}

It is perhaps not surprising that the test and its categories would obscure the lens provided by the ASP taking stock and inquiry process and lead to an over emphasis on improving test scores rather than improving teaching and learning. As Hill and other schools respond to the requirements of the No Child Left Behind Act and strive to make and maintain Adequate Yearly Progress, it is logical for teachers to emphasize the standardized test as the primary data source for judging their teaching effectiveness. Teachers did not have access to the observation data yielded by the CIERA classroom observation scheme that we collected. (The data have since been shared with the faculty.) On the other hand, the members of the reading cadre also did not seem to use the wide variety of data they collected during taking stock, including their own surveys, student work samples, and teachers' concerns about reading instruction, to inform their inquiry process or to set priorities for the next school year. 
Although the ASP processes afforded opportunities to identify and analyze other data on teaching and learning, an unyielding focus on the test and the test data trumped any other focus on what teachers knew about the readers in their classrooms, about what they knew about their students as writers, and/or about how their students had performed on literacy assignments in their classes. The test was considered the penultimate and sole measure of performance. According to Meier (2004), external pressure to use only test data to measure our learners leads to even more confined lenses for reform, where the very definition of an educated person is controlled by our federal government through the NCLB act's accountability measures. To Meier, current state and federal polices have led to an environment where "A well educated person is who scores high on standardized tests. And ergo a good school is one that either has very high test scores or is moving toward them at a prescribed rate of improvement. Period" (p. 67).

Kohn (2004) warns that we should not "sacrifice" good teaching "on the altar of accountability" (p. 575). He explains that developmentally appropriate teaching, and innovations like project-based learning, music instruction, and field trips will be the "collateral damage" of NCLB. We must not allow NCLB or any other state accountability policy to have us forget what we know about real school reform.

Reform can be undertaken without sacrificing good instruction. In The Power of Their Ideas Meier (2002) recounts how she, a band of teachers, and a handful of community members reformed one school at a time until they had inspired a school reform movement which had profound effects on the entire New York Public School System. One size fits all assessment programs like NCLB were not a part of this reform effort.

As this report is being written, Hill Elementary is beginning its second year of implementation of Accelerated Schools Plus. Professional development time has been set aside to continue cadre meetings, collect data, put action plans into place, work on priorities set at the end of the first year, and to evaluate results. ASP aims to improve school achievement globally, through changed governance structures and teacher-led decision making, as well as within classrooms, through professional development and frequent teacher interaction. ASP promises to help teachers accelerate learning by teaching them to use "Differentiated Instruction" and "Powerful Learning" (Boyd, 2003). Differentiated Instruction means that teachers assess students carefully, and adjust teaching to individuals based on strengths. As a result, students are meant to engage in increasing amounts of small group and individual instruction, blended with whole class instruction. Powerful Learning is an approach in which teachers ask children to engage in what is described as authentic, inclusive, learner-centered, interactive, and continuous units of study." During Powerful Learning, students are supposed to have opportunities to make connections between real-world and classroom experiences; to solve real-world problems that are built from the concerns and interests of children; that involve active learning; and that require long-term study. The Accelerated Schools representative has already begun to provide professional development on Powerful Learning and Differentiated Instruction.

Teachers were hopeful that the ASP processes and professional development would help them improve instruction. Observations suggest one improvement might be to decrease time spent in whole class instruction, Ms. Sanders hoped ASP would help her do that.

Their [students'] biggest need is probably more one-on-one. So many of them, you know, they just need you right there with them. I don't know that Accelerated Schools may, it may, with more teaming of, you know, more peer interaction where they can work together. 
All of the teachers we spoke to hoped that comprehensive school reform would help them to improve instruction. The teachers at Hill wanted to improve not just test scores, but teaching and learning in general. While the emphasis on external accountability affected the reform process during the first year of implementation, teachers remained hopeful that subsequent years would provide more powerful change. As Ms. Sanders told us, "I hope it will of course it will bring about better test scores because we need that. But I also hope that it will give me some tools for some powerful learning, to go on in the classroom, and some more meaningful lessons. . . I I guess it's coming, it's just slow." Teachers were willing to continue with the ASP process at the end of the first year, even though they had not yet seen noticeable changes. It remains to be seen whether long term involvement

with the Accelerated Schools Plus model will cause teachers to redefine their definitions of quality literacy teaching and to set new and more nuanced priorities for improving reading instruction.

\section{Works Cited}

Allington, R.L. (2002). What Really Matters for Struggling Readers. New York: Longman.

Bloom, H.S. (2003). Using "short" interrupted time-series analysis to measure the impacts of whole-school reforms: With applications to a study of Accelerated Schools. Evaluation Review, 27, pp. 3-49.

Borman, G.D., Hewes, G.M., Overman, L.T., \& Brown, S. (2003). Comprehensive school reform and achievement: A meta-analysis. Review of Educational Research, 73, pp. 125230.

Boyd, T. (2003). Accelerated Schools PLUS: Research base for selected services. Imagine . . . Accelerated Schools Plus Newsletter 12 (3) , pp 8-16. University of Connecticut NEAG School of Education. Retrieved August 9, 2004 from www.acceleratedschools.net.

Byers, G.O. (2001). Daily Oral Language. Greensboro, NC: Carson Dellosa Publishing.

Duke, N.K. (2000). 3.6 minutes per day: The scarcity of informational texts in first grade. Reading Research Quarterly, 35, 202-224.

Elley, W.B., \& Mangubhai, F. (1983). The impact of reading on second language learning. Reading Research Quarterly, 19, 53-67.

Fountas, I.C. \& Pinnell, G.S. (2001) Guiding readers and writers (grades 3-6): Teaching comprehension, genre, and content literacy. Portsmouth, N.H.: Heinemann.

Guthrie, J.T., Schafer, W.D., \& Huang, C. (2001). Benefits of opportunity to read and balanced instruction on the NAEP. Journal of Educational Research, 94, 145-162.

Hopfenberg, W.S. \& Levin, H.M. (1993). The accelerated schools resource guide. San Francisco: Jossey-Bass.

Knapp, M.S. (1995). Teaching for meaning in high-poverty classrooms. New York: Teachers College Press.

Knight, S.L., \& Stallings, J.A. (1995). The implementation of the Accelerated School Model in an urban elementary school. In R.L. Allington \& S.A. Walmsley (Eds.), No quick 
fix: Rethinking literacy programs in America's elementary schools (pp. 236-251). New York: Teachers College Press.

Kober, N. (2001). It takes more than testing: Closing the achievement gap. (UD 034 289). Washington DC: Center on Education Policy (Eric Document Reproduction Service No. ED 454 358)

Kohn, A. (2004). Test today, privatize tomorrow: Using accountability to 'reform' public schools to death. Phi Delta Kappan 85, 8, 568-577.

Levin, H.M. (1987). Accelerated schools for disadvantaged students. Educational Leadership, 44, pp. 19-21.

Meier, D. (2002). The power of their ideas. Boston: Beacon Press.

Meier, D. (2004) NCLB and democracy. In Meier, D. \& Wood, G. (Eds.) Many children left behind: How the no child left behind act is damaging our children and our schools (pp. 6678).. The forum for education and democracy. Boston: Beacon Press: Boston.

Miron, L.F., St. John, E.P., \& Davidson, B. (1998). Implementing school restructuring in the inner city. The Urban Review, 30, pp. 137-165.

National Center for Accelerated Schools Plus, The Accelerated Schools Project, http://www.acceleratedschools.net (2 September 2005).

National Reading Panel. (2000). Report of the National Reading Panel. Washington, CD: National Institute for Child Health and Human Development.

Pressley, M., Wharton-McDonald, R.; Allington, R., Block, C. C., Morrow, L., Tracey, D., Baker, K., Brooks, G., Cronin, J., Nelson, E., \& Woo, D. (2001). A study of effective firstgrade literacy instruction. Scientific Studies of Reading, 5, 35-38.

Purcell-Gates, V. (2002) “. . . As soon as she opened her mouth!”: Issues of language, literacy, and power. In Delpit, L. (Ed.) The skin that we speak. New York: The New Press.

Renaissance Learning. (2004. Accelerated Reader. Retrieved August 9, 2004 from http://www.renlearn.com/ar/default.htm.

Stallings, J.A., \& Kaskowitz, D. (1974). Follow Through classroom observation evaluation 1972-1973 (SRI Project URU-7370). Stanford, CA: Stanford Research Institute.

Taylor, B.M., Frye, B.J., Maruyama, G.M. (1990). Time spent reading and reading growth. American Educational Research Journal, 27, 351-362.

Taylor, B.M. \& Pearson, P.D. (2000). The CIERA School Change Classroom Observation Scheme. Ann Arbor, MI: Center for the Improvement of Early Reading Achievement, University of Michigan.

Taylor, B.M., Pearson, P.D., Clark, K.F., \& Walpole, S. (1999). Beating the odds in teaching all children to read. (CIERA Report \#2-006). Ann Arbor, MI: Center for the Improvement of Early Reading Achievement, University of Michigan.

Taylor, B.M., Peterson, D., Rodriguez, M.C., \& Pearson, P.D., (2002). The CIERA school change project: Supporting Schools as they implement home-grown reading reform. (CIERA Report \#2-016). Ann Arbor, MI: Center for the Improvement of Early Reading Achievement, University of Michigan. 


\section{Abstract}

This article examines a rural elementary school's first year of implementation of a comprehensive school reform model, Accelerated Schools Plus. Teachers at this school were found to engage in literacy teaching practices consistent with moderately (but not high) performing schools, with strengths such as high levels of student engagement and relatively frequent coaching of students, and weaknesses such as infrequent teaching of comprehension and an almost exclusive use of passive instruction such as recitation. The reform model purports to help teachers to recognize such strengths and weaknesses, however, a focus on standardized test scores and accountability hampered teachers' implementation of the reform model.

\section{Authors' Biographies}

Devon Brenner is an Assistant Professor of Reading and Language Arts at Mississippi State University. Contact: devon@ra.msstate.edu.

Kay Brocato is an Assistant Professor of Education Foundations in the Department of Curriculum and Instruction at Mississippi State University. Contact: dkb3@ra.msstate.edu.

Terri Barber Kurz is a Reading Specialist for the University of Texas at Austin University Charter Schools. Contact: tkurz@mail.utexas.edu. 